\title{
SEGREGATED NEIGHBOURHOODS AND THEIR INTEGRATION ATTEMPTS: PARTICIPATORY SLUM-UPGRADING IN THE MAKING
}

\author{
DOI: 10.18485/arh_pt.2020.7.ch61
}

\author{
- Tímea Csaba \\ PhD student, University of Pécs, Faculty of Sciences, Institute of Geography, \\ Department of Human Geography and Urban Studies, Doctoral School of \\ Earth Sciences, H-7624 Pécs, Ifjúság útja 6., csabatimi@yahoo.co.uk
}

\begin{abstract}
As the proliferation of informal settlements has gained pace around the world, often coupled with spatial and social segregation, the global community has made efforts to provide a set of norms to tackle the issue. From the UN Sustainable Development Goals, a clear message takes shape for urban experts and decision makers: the focus is from now on social inclusion and community building; a priority before infrastructural intervention. The offered tool, named Participatory Slum-upgrading Program (PSUP) draws up a guide suitable not only for the Global-South but for urban rehabilitation projects of segregated areas in the developed world, too. The challenge is not only to implement global recommendations to local context but to measure the projects' effectiveness in order that we can learn from each other: to be able to decide at a glance whether a project supports social integration and strengthens communities. To answer this need, a tentative index is tested on two case-studies. One that had begun as an urban experiment but at the end turned out to be a model of social urban rehabilitation in Pécs (HU), and the second one in Siklós (HU) implementing the former model, is a live project, still running. The background and process of the two cases are analyzed according to the index to demonstrate their comformation to the PSUP principles. On the side, the importance of process-design will also be examined.
\end{abstract}

KEYWORDS _ participatory slum-upgrading, urban rehabilitation, informal settlements, socio-spatial exclusion, Roma integration

\section{INTRODUCTION}

"Informality is neither good, nor inherently bad - it simply is." (Brillembourg, 2010). This claim by Urban Think Tank hints at the scale of a phenomenon already present world-wide: the proliferation of slums, or better said: informal settlements. The UN estimates above 1 billion people to reside in conditions that are inhuman: lack of access to basic infrastructure and utilities, precarious housing conditions, constant threat of forced eviction. Although associated largely with the Global-South, the presence of informal settlements with inhabitants living in extreme poverty is still an unsolved issue in the developed world. $6 \%$ of the world's population living in extreme poverty are located in the developed world, indicating around 54 million people (UN-Habitat, 2013). As slums are still expanding and spreading around the globe, efforts have been made in international conferences, with $\mathrm{UN}$-Habitat in the leading role, to reach consensus on the issue.

The international community intends to create a corpus of norms that would be further implemented and discussed locally in each country, in partnership with local authorities. This is the Sustainable Development Goal (SDG) with 17 goals to reach until 2030. Its leading idea calls for the harmonization of economic growth, social inclusion and environmental protection (UN-Habitat, SDG). In fact, from an urban planner/designer point of view, one may observe a novel focus: the strategic plans 
all name social inclusion as their main organizational priorities, from which all areas of work shall derive. It officially frames a tendency in urban planning, tangible since the '90s: the importance of social integration as integral part of urban rehabilitation projects (Egedy, 2005). This is closely linked to resilience: the ability of a community to adapt and renew itself in the face of crisis. (Pirisi, 2019) According to the UN-Habitat, resilience of a certain city or neighbourhood may be reached through empowerment of communities. To offer a tool for urban experts and decision makers around the world, UN-Habitat has developed PSUP - Participatory Slum-upgrading Program, where under a global recommendation framework, the actions shall be adapted to local context by local governments (UN-Habitat, PSUP).

\section{METHODOLOGY}

As the urban strategies concerned with the improvement of slums evolved from eradication and resettlement, through isolated infrastructural interventions, to complex upgrading (Pamuk, 1998) and recently to social inclusive and participatory approaches; the number of case-studies in international scientific literature grew exponentially. As each informal settlement is a unique case, affected by a complex array of political, environmental and social impacts (Neuwirth, 2005), which are specific to the local context, the analysis of interventions and their outcome are generally performed case by case. When searching for comparison of the results, one can rely only on quantitative data, such as the UN-Habitat's statistical analysis on slum development for developing countries (UN-Habitat, 2015). What is missing, however, is a common platform evaluating qualitative results: the effectiveness of the slum-upgrading programs.

Since UN-Habitat offers a "globally" valid method for slum-upgrading, the PSUP, it seems logical to use its criteria as an umbrella to measure the success of individual interventions. Is there a way to objectively show on a diagram whether a neighbourhood renewal project supports social integration and strengthens communities? Are European urban rehabilitation practices conform with the principles of the PSUP?

To test these ideas, two case-studies were chosen, both social urban rehabilitation projects of segregated urban neighbourhoods in South-Hungary. Through in-depth interviews with the two project managers of the urban rehabilitation processes and the documentation provided by the two municipalities, the projects' details were gathered. In Siklós, where the rehabilitation is still ongoing, it was possible to participate in some of the social programs organized for the locals. This helped understand the real depth of involvement of the residents, their motivation and interest for change. The advantage of the other site, Pécs-Kelet was that the rehabilitation project was closed 5 years ago, so it was possible to examine the project from the perspective of social sustainability. Here interviews with residents of two neighbourhoods (Györgytelep and Pécsbánya) revealed details on the impact of social coaching at individual levels, which in return effected the integration of the whole community. These were all valuable first-hand information, which contributed to the evaluation of each project according to the new set of criteria.

\section{TOWARDS A GRAPHICAL EVALUATION INDEX FOR SLUM-UPGRADING PROJECTS}

PSUP is defined by UN-Habitat as an urban renewal process where slum-dwellers are in the centre of change: they participate in decision-making, in design, in implementation and even in monitoring and follow-up. Their individual development and contribution lead to the strengthening of the community, and by feeling ownership over the project they are more willing to take over (also characteristic of a resilient community). Their change of mind-sets results in citizen empowerment. PSUP on the other hand also calls for cooperation on a multi-stakeholder platform.

Do current European urban rehabilitation practices, aimed at marginalised and spatially segregated neighbourhoods correlate with this? In what extent? 
During the early 2010s an urban rehabilitation program in Pécs (South-Hungary), has become a model project, in what Hungarian urban literature calls social urban rehabilitation. It is because of its detailed work on individual coaching and community development, which foregoes the infrastructural intervention. It is referred to as the Pécs-model and will be discussed in the next paragraph. Another project, working with segregated neighbourhood in the small town of Siklós, $30 \mathrm{~km}$ to the South from Pécs, has chosen the Pécs-model as its reference and built its subsidy application and urban regeneration program after the former. Although the method was the same, the result surprisingly is less community oriented and effects a larger rate of inhabitants to move out.

To be able to represent differences of the two projects on a single graphical overview, the main criteria of the PSUP were extracted. These are all qualitative values, scoring from 0 to 10: 1. partnerships - whether a project invites various stakeholders to cooperate on the same platform. 2. Individual help - whether inhabitants are offered individual coaching in education, job-training, bureaucracy and legal assistance, family and psychological consultation, etc. 3. Community organization - how strong a program supports community building. 4. Contribute - the rate of (possible) contribution of inhabitants. Whether they are given the possibility to participate in the execution of the renewal of their residence. 5. Involvement - whether or not slum-dwellers are given the opportunity to contribute their ideas in the design or have a say in the decision-making process. 6 . Infrastructural development - the rate of renewal of community spaces and public buildings. 7. Environmental safety - whether the program enables an environmentally safe home for the inhabitants (public utilities, structural stability of the house). 8. Elevate economic status - a key message of a social rehabilitation project is always that social upgrade of the inhabitants is essential for the successful and sustainable upgrading of the neighbourhood. (The graphical representation was inspired by the European Green-City Index. (Shields))

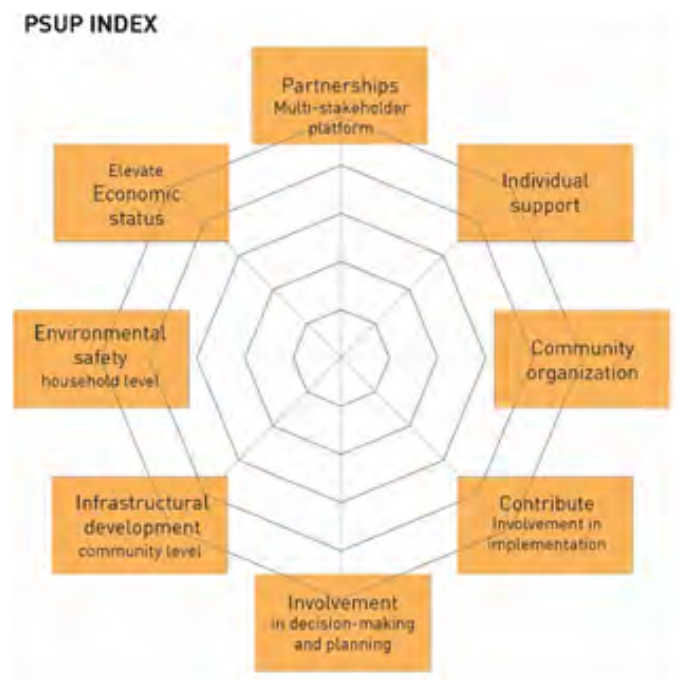

_ Fig. 1: PSUP index, main criteria

The resulting diagram will be a representation of social inclusion and social-oriented approach of urban rehabilitation: the larger the area on the diagram covers, the larger the citizen-involvement and need-based planning is.

Besides, it appeared crucial to understand the causes leading to different results while working with the same model. Since the implementation of the norms and their adaptation to local context is up to the local government, the background of each segregation and the renewal process itself will be analysed. 


\section{THE PÉCS MODEL}

In Hungary extreme poverty has regained significance as the gap between rich and poor keeps widening again. The Gypsy minority is condemned to spatial segregation: their social exclusion tends to drift them towards residential segregation, into so-called Gypsy-settlements or villages inhabited solely by the Gypsy. Although not restricted to ethnicity, people in extreme poverty are often exposed to living conditions that define as slums according to the UN-Habitat: they often lack access to sanitation, basic utilities, their housing conditions are characterized by poor structural quality and overcrowdedness (UN-Habitat, 2015b). The legal status under which they inhabit their houses is often insecure. How many people are concerned? In Hungary in $2012,17 \%$ of the total population lived in income poverty, which was down to 13.4\% in 2017 (TÁMOP, 2014, Eurostat, 2019a), however, still well above the European average of $6 \%$. Regional differences are significant: poverty rate in the capital is $6 \%$, in county seats it is $17 \%$ and the largest rate we observe is on the countryside with $25 \%$ of the local population (TÁMOP). Mid-size towns have larger segregation indexes (13.8\%) than county seats $(8.1 \%)$. Coupled with emigration, these smaller towns are more vulnerable to spatial segregation. (Koós, 2020). It is worth mentioning that poverty in Eastern-Europe is more typical for the countryside, whereas we speak about urban poverty in Western-Europe. Nonetheless, Hungary spent only $18.9 \%$ of its GDP on social protection in 2016, compared to the European average of $28 \%$ (Eurostat, 2019b).

It was therefore essential for Hungarian towns and villages to apply for European subsidies targeting poverty reduction. In 2011 started a new series in funding, called TÁMOP (Operative Program for Social Renewal) that distributed EU-subsidy to settlements that applied with social programs aiming to "mitigate the deepening, the reproduction and the spread of poverty, and to promote integration for those living in extreme poverty". (TÁMOP) They were social programs, intending to promote community building, to improve access to public services and to involve the inhabitants. The frame on how to implement these principles were relatively loose. Between 2011-2014, 25 projects received funding, and since all were tailored to local needs, 25 different methods responded to the initial challenge. The projects lasted in average 2,5 years. The conclusion was that break-through can only happen if the projects are participatory, and if all stakeholders of the area participate in the planning and creation of a common future vision.

The project of Pécs-Kelet - who first applied with a single segregation, called Györgytelep - has grown out into a model-project between 2012-2015 as the municipality successfully built one funding on top of the previous. Pécs-Kelet is on the North-East fringe of the city of Pécs and consists of five former miners' colonies, all declared segregation at the 2001 census. As a prerequisite of the rehabilitation program, such an area was chosen where already social workers and local associations had been present. The first funding, TÁMOP 5.3.6-11/1. worked with social-coaching of the people: it prepared them with job-training, after-school education, individual development plans, health-care services and community programs. Second, Pécs received another type of subsidy for infrastructural renewal, called TIOP, which enabled the city to rehabilitate individual homes, introduce missing public utilities, rebuild public space, community house and a social centre in the area of the segregation. A third funding, Natura, assured that even after the works were completed, the residents receive the individual social care from the first program. This latter is referred to as the "follow-up" phase. It was a multi-stakeholder cooperation: municipality of Pécs, local NGOs, social workers, Roma associations and even the Faculty of Architecture of the University of Pécs participated. The life-conditions of the 30 families (around 100 people) significantly ameliorated as well as the image of the area.

After the experimental start it became clear that the sequence of interventions is key for a socially sustainable result: social coaching of the inhabitants first, infrastructural rehabilitation next and approximately 3 years of social follow-up to complete. In this regard, process design is essential. With the same model, the municipality of Pécs was able to renew the neighbouring four other segregations. It needed a total of 6 successful funding applications in $3 \mathrm{EU}$ funding cycles to rehabilitate 5 segregated neighbourhoods. 


\section{Siklós Váralja - Segregation spanning across centuries}

The segregation area of Siklós Váralja is unique both in location and in history. It lies at the shadow of a listed monument, the Siklós castle (Váralja means "below the castle") and has been the edge of the town even as of today, as the adjacent polder prevented the town to spread in that direction. It evolved historically into a segregation, as Váralja was the place for service people of the castle, who belonged to the poorest population.

Váralja was declared segregation also at the 2001 census. The population rate of the working-age (15-59 years) residents is $+17 \%$ above the average of Siklós, nonetheless, only $24.6 \%$ of them are employed, and unemployment rate in the segregation is $46.9 \%$. The houses are low in comfort ( $27.3 \%$ compared to $5 \%$ in the town), and $9.3 \%$ of them have only one room. They are constructed on a terrain that is vulnerable to landslides, as it happened in $2013 \mathrm{e.g}$. This situation is aggravated by the fact that sewage system of individual households is often not linked into the public utility system. (Siklós, Project Plan)

The late 20th and 21 st century have put the segregation into a real-estate trap: it now lies in the triangle of the touristic castle, the bus terminal as well as a four-star hotel and spa. As such, the first attempts of renewal were not that of rehabilitation but of slum-clearance. The municipality of Siklós applied with the same model of urban rehabilitation as Pécs for EU-subsidy and is currently running the urban rehabilitation project. The rehabilitation process runs according to the Pécs model: social coaching first, infrastructural intervention next.

\section{PARTICIPATORY SLUM-UPGRADING IN EASTERN-EUROPE? - PROGRAM ANALYSIS}

What answers did each municipality give to these different set of issues? In order to be able to compare the different outcomes of the two projects, the program elements of each rehabilitation are examined according to the PSUP index mentioned above. During the analysis, we shall bear in mind the largest difference between the two projects: whereas in Pécs-Kelet the municipality owned $100 \%$ of the dwellings, in Siklós the houses were all in private ownership.

\section{Rehabilitation project Pécs-Kelet (5 settlements)}

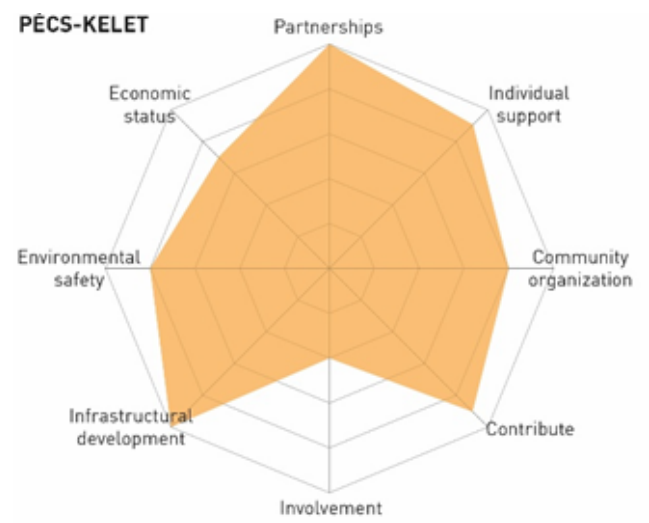

_ Fig.2: PSUP index for Pécs-Kelet

1. Partnerships: Municipality of Pécs (also head of county) founded the success of the rehabilitation project by involving a wide range of stakeholders: it applied for the EU funding together with the Maltese, who were responsible on-site for the individual social-coaching, the recording of every-day life of slum-dwellers, so they knew exactly who is eligible (and capable) to move into a renewed dwelling and pay the monthly costs. The municipality also worked together with local Roma associations, 
other NGOs and the UNDP (United Nations Development Program). 2. Individual support: PécsKelet ranks high on supporting people individually. Inhabitants received according to age and need: job-training, coaching in job-search, language and IT courses, consultancy on legal issues, family guidance, after-school programs for kids, psychological assistance and health-care programs. 3. Community organization: Another strength of the projects were the large variety of available social programs that brought together the community. 4 types of club programs, 5 types of workshops and 8 thematic days took place in the Community house. 4. Contribute: inhabitants were able to participate in the rehabilitation works themselves. Those who were trained during the individual programs as mason and painter helped rebuild the houses. The Men's club founded during the community programs was the one that rebuilt the main staircase of Györgytelep, which counts as the main "public square" of the neighbourhood. 5. Involvement: Pécs-Kelet received a lower score on involvement in decision-making. This is because the community was strengthened during the project. However, at the redesign of some of the public square, participatory workshops helped define the main needs of inhabitants (eg. at Hösök tere). 6. Infrastructural development: building for the community reached highest score in Pécs-Kelet project. All 5 settlement-rehabilitation projects involved the following: one public square renewal, one community house, one social centre (both as transformation of existing buildings, e.g. the reconstruction of the former movie theatre in Györgytelep) and public utilities renewal (e.g. rain drainage system under the road). 7. Environmental safety: individual homes were completely reconstructed, smaller ones merged into larger homes that required the reshuffling of the residents. Basic infrastructure was installed: cooking stove, running water inside the house. A negative point goes for the heating with wood but this could not be avoided as people would not have been able to pay for the costs of central heating. 8. Economic status: the formation for basic jobs (33 people in Györgytelep), the active job-search coaching contributed to the integration of the inhabitants to the society, however, many of them abandoned later on the new skills and finished working for communal works (employment by the state for half of the official minimal wage).

All in all, the involvement of the inhabitants was significant in all 5 settlements and this contributed to the fact that inhabitants feel the place their own, even if they rent the houses from the municipality.

\section{Rehabilitation project Siklós Váralja}

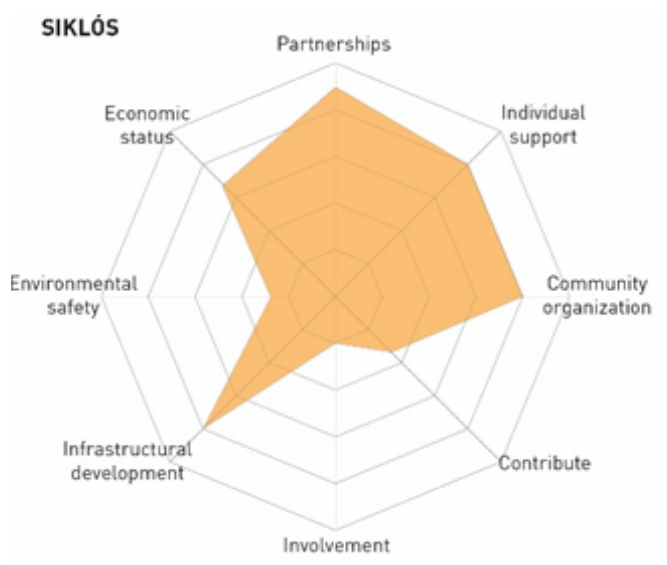

_ Fig.3: PSUP index for Siklós Váralja

1. Partnerships: Municipality of Siklós has created a multi-stakeholder platform, though with less actors, since there were no local associations in the neighbourhood. Their partners were: Municipality of Baranya County, Helping Families Service, MIOK Association for the Disadvantaged who is responsible for the constellation of social programs. 2. Individual support: high score goes for 
individual life-coaching of inhabitants. The Helping Families Service guides families through bureaucratic services, loan problems and ownership difficulties. A few job-trainings were conducted, and active job-search is on the agenda. Children receive after-school programs. 3. Community organization: following the Pécs-model, Váralja has been organizing 7 different types of community programs for 2 years, including one called Napraforgó, where inhabitants went on an excursion to different cities to see best practices of Roma entrepreneurs. 4. Contribute: apart from learning to maintain their garden, inhabitants have little possibility to contribute to the renewal of their surroundings. 5. Involvement: during the project, the inhabitants did not have the possibility to take part in decision-making processes, nor in the design. Public hearing took place at the start of the project. 6. Infrastructural development: Váralja receives high scores for the intervention planned for its public space: sewage-pipe and road reconstruction, new pavements on the main street and reinforcement of the city-wall. The municipality has started the process to buyout 19 houses, since it has no ownership in the area. Those houses will be demolished, in order to make place for a public space and two newly constructed houses: a vigilante house and a house for communal workers. The community house is at the moment a transformed family house. 7. Environmental safety: although the municipality contributes with public utility renewals to the safety of the neighbourhood, it has no possibility to intervene inside the individual households. Sewage of individual houses is not modern and does not connect to the main pipe as owners cannot afford the installation. This undermines the already precarious stability of the lands, vulnerable to landslides. Another ecological problem is the heating with wood, as the smoke culminates in the highest, 3rd row of houses, just below the city-wall. 8. Economic status: 20 persons (in their active age) received education close-up, followed by job-training and job-search training. Those who participated, received financial support for the time of the trainings as a motivation.

Basic difference is that the municipality had little room to intervene at household level as houses are in individual hands. To compensate this, Siklós has agreed to buy out 19 houses, whose residents will move out into "integrated setting" in the town. Currently, this involves 14 families of the segregation out of 64 . What will happen once the project will have reached its social aim: the community will be strengthened, and then third of the inhabitants will need to leave? It also raises questions for the future of the neighbourhood that the municipality's main reason behind the rehabilitation is to turn the area attractive for tourists.

\section{CONCLUSION}

As the scientific literature on slum-improvement consists mostly of individual case-studies, there is an unwritten need for comparing these. One key issue in slum-upgrading is whether it works on the long-run: does it result in social inclusion and community building? UN-Habitat's Participatory Slum-Upgrading Program aims at this long-term success: if a community is strengthened via its individuals and acts as one body, its overall resilience will rise, and the community will leave the downward spiral of segregation. The developed graphical tool extracts the essence of PSUP down to 8 evaluation criteria, all qualitative.

Comparing individual case-studies is a risky issue, as contextual differences might make one urban strategy un-appliable in even a neighbouring area. The aim of creating the index is therefore only the evaluation of participatory slum-upgrading programs: whether they are socially inclusive for the residents, and as such might be a guarantee for social sustainability. It leaves contextual differences for background explanation.

This can be best demonstrated by comparing the two tested case-studies: the index for Pécs-Kelet covers a larger area, it involved more residents during the urban rehabilitation. They were individually coached, they helped rebuilding the residential houses and the public space, they participated in community-building programs. The houses were municipally owned, whereas in Siklós residential houses are in private hands. For Siklós-Váralja, the index covers a smaller area: residents are involved in individual coaching, take part in social programs, however, third of the total inhabitants 
will soon need to move out of the neighbourhood, in order for their houses to be turned into public buildings. This originates in the main motivation of the municipality to slowly transform the area attractive for tourists. Although Siklós has applied the same rehabilitation model for Váralja as PécsKelet, because of political motivation (and only in part because of tenure issues), the end-result will be a less socially inclusive one.

The PSUP index is yet in an idea-phase: it now proved context-independent within one country but for comparison of international case-studies, it needs further research. As well as the exact method of scoring still needs to be fine-tuned.

\section{REFERENCES}

- Brillembourg, A., Klumpner, Hubert. 2010. "On the road again" In: New Towns for the 21st Century, edited by Provoost, M. 208-219. Amsterdam: Bertrams.

_ Egedy, T. (Ed.). 2005. Városrehabilitáció és Társadalom. Budapest: MTA Földrajztudományi Kutatóintézet

_ Eurostat: "Income poverty statistics". Last updated: May 2019. https://ec.europa.eu/eurostat/statistics-explained/index.php?title=Income_poverty_statistics

_ Eurostat: "Social protection statistics". Last updated: Nov. 2019. https://ec.europa.eu/eurostat/statistics-explained/index.php?title=Social_protection_statistics\#Social_protection_expenditure_and_GDP_ rates_of_change

_ Koós, Bálint. 2020. "Városi zsugorodás és lakóhelyi szegregáció Magyarországon", Tér és Társadalom, 34(1), p. 48-68. doi: 10.17649/TET.34.1.3182

- Neuwirth, R. 2005. Shadow Cities. New York, NY: Routledge

_ Pirisi, Gábor. 2019. "The interpretation of the concept of resilience for researchers in urban geography". In: Tér és Társadalom, 33, no.2.: 62-81. https://doi.org/10.17649/TET.33.2.3080

_ Shields, K. European Green-City Index. 2009. Munich: Simens AG

- Siklós Project plan for the rehabilitation of Siklós Várlja - received from the Municipality of Pécs in PDF, 2016. Title: Társadalmi együttműködés erősítését szolgáló komplex program Siklós - Váralja szegregátum társadalmi, gazdasági integrációja érdekében. Projektelőkészítő tanulmány.

- TÁMOP 5.1.3. 2014. Közösségi felzárkóztatás a mélyszegénységben élők felzárkóztatásáért. Zárókiadvány. ISBN: 978-963-08-9192-9

_ United Nations: Sustainable Development Goals (SDG). https://www.un.org/sustainabledevelopment/ sustainable-development-goals/

_ UN-Habitat. 2015. Slum Almanac 2015-2016. Tracking Improvement in the Lives of Slum Dwellers. Retrieved from: http://unhabitat.org/slum-almanac-2015-2016/

- UN-Habitat. 2015. The Habitat III Issue Papers. 22 - Informal Settlements. http://habitat3.org/ wp-content/uploads/Habitat-III-Issue-Paper-22_Informal-Settlements-2.0.pdf

_ UN-Habitat. 2013. European Cities in Transition. https://unhabitat.org/sites/default/files/download-manager-files/State_of_European_Cities_English_Version.pdf

_ UN-Habitat. 2007. Slum Dwellers to double by 2030: Millennium Development Goal Could Fall Short. UN-Habitat, Twenty First Session of the Governing Council, April, 3.

_ UN-Habitat: Participatory Slum-Upgrading (PSUP). https://www.mypsup.org/topics/Participation 